\title{
Heat Shock Protein 27: Developmental Regulation and Expression after Peripheral Nerve Injury
}

\author{
Michael Costigan, ${ }^{1,2}$ Richard J. Mannion, ${ }^{1,2}$ Giles Kendall, ${ }^{1}$ Susan E. Lewis, ${ }^{2}$ Jason A. Campagna, ${ }^{2}$ \\ Richard E. Coggeshall, ${ }^{3}$ Jacqueta Meridith-Middleton, ${ }^{1}$ Simon Tate, ${ }^{4}$ and Clifford J. Woolf ${ }^{1,2}$ \\ 'Department of Anatomy and Developmental Biology, University College London, London WC1E 6BT, United Kingdom, \\ ${ }^{2}$ Neural Plasticity Research Group, Department of Anesthesia and Critical Care, Massachusetts General Hospital and \\ Harvard Medical School, Boston, Massachusetts 02129, 32Department of Anatomy and Neurobiology, University of Texas \\ Medical Branch, Galveston, Texas 77551, and ${ }^{4}$ Glaxo-Wellcome Research and Development, \\ Gene Function Unit, Stevenage, Herts SG1 2NY, United Kingdom
}

The heat shock protein (HSP) 27 is constitutively expressed at low levels in medium-sized lumbar dorsal root ganglion (DRG) cells in adult rats. Transection of the sciatic nerve results in a ninefold upregulation of HSP27 mRNA and protein in axotomized neurons in the ipsilateral DRG at $48 \mathrm{hr}$, without equivalent changes in the mRNAs encoding HSP56, HSP60, HSP70, and HSP90. Dorsal rhizotomy, injuring the central axon of the DRG neuron, does not upregulate HSP27 mRNA levels. After peripheral axotomy, HSP27 mRNA and protein are present in small, medium, and large DRG neurons, and HSP27 protein is transported anterogradely, accumulating in the dorsal horn and dorsal columns of the spinal cord, where it persists for several months. Axotomized motor neurons also upregulate HSP27. Only a minority of cultured adult DRG neurons are HSP27immunoreactive soon after dissociation, but all express
HSP27 after $24 \mathrm{hr}$ in culture with prominent label throughout the neuron, including the growth cone. HSP27 differs from most axonal injury-regulated and growth-associated genes, which are typically present at high levels in early development and downregulated on innervation of their targets, in that its mRNA is first detectable in the DRG late in development and only approaches adult levels by postnatal day 21 . In non-neuronal cells, HSP27 has been shown to be involved both in actin filament dynamics and in protection against necrotic and apoptotic cell death. Therefore, its upregulation after adult peripheral nerve injury may both promote survival of the injured neurons and contribute to alterations in the cytoskeleton associated with axonal growth.

Key words: dorsal root ganglion; axotomy; differential gene expression; apoptosis; spinal cord; regeneration
Peripheral nerve injury alters gene expression in primary sensory neurons. This includes the upregulation of developmentally regulated growth-associated genes, such as GAP-43, that lead to the capacity to initiate and sustain neurite outgrowth (Chong et al., 1992; Aigner and Caroni, 1995) and some cytoskeletal proteins, including $\beta$-tubulins and actin (Miller et al., 1989; Moskowitz and Oblinger, 1995), which may modify the cytoskeleton, facilitating axonal growth. There are, in addition, atrophic changes attributable to loss of contact between the neuron and its peripheral target, such as the downregulation of neurofilament expression (Wong and Oblinger, 1991). This results in a reduction of axon caliber and cell volume, as well as synaptic terminal degeneration (Aldskogius et al., 1985; Castro-Lopes et al., 1990; Gold et al., 1991). In some neurons, peripheral nerve injury leads to cell death, although in the adult, unlike the neonate (Yip et al., 1984), death of primary sensory neurons occurs only after a long delay ( $>16$ weeks) and is limited to neurons with unmyelinated axons (Coggeshall et al., 1997). Finally, there are a number of diverse

\footnotetext{
Received March 30, 1998; revised May 6, 1998; accepted May 8, 1998.

This work was supported by Medical Research Council Grant G9431792, Human Frontiers Science Program Grant RG73/96, European Union Grant BMH4-CT 95 0172, Glaxo-Wellcome, and the Triangle Trust.

M.C. and R.J.M. contributed equally to this work.

Correspondence should be addressed to Dr. Clifford J. Woolf, Neural Plasticity Research Group, Department of Anesthesia and Critical Care, Massachusetts General Hospital and Harvard Medical School, 149 13th Street, Room 4309, Charlestown, MA 02129

Copyright (C) 1998 Society for Neuroscience $\quad 0270-6474 / 98 / 185891-10 \$ 05.00 / 0$
}

phenotypic changes in axotomized neurons that alter the function and signaling capacity of the neurons and that include the downregulation of some neuropeptide neuromodulators, the upregulation of others, and modified expression of receptors and ion channels (Hokfelt et al., 1994).

A challenge then is to determine which signals initiate changes in neuronal gene expression after peripheral nerve injury, what the changes are, and how they alter the properties of the cell and the function of the somatosensory system. As a first step, we have used a PCR-based subtractive hybridization technique (Brady et al., 1995) to look for those genes upregulated in adult rat primary sensory neurons after peripheral nerve injury. Among the first set of identified regulated clones was the heat shock protein (HSP) 27 (Uoshima et al., 1993).

Constitutive expression of HSP27 has been described recently in a subset of sensory and motor neurons (Plumier et al., 1997). HSP27, like other heat shock proteins, is upregulated after ischemic damage to the brain (Kato et al., 1994; Higashi et al., 1997). However, little else is known about the expression or function of HSP27 in the nervous system. HSP27 in non-neuronal cells has a number of functions in cellular repair, acting as a molecular chaperone (Jakob et al., 1993) and altering cell motility by modulating actin dynamics (Lavoie et al., 1993b, 1995; Benndorf et al., 1994; Mairesse et al., 1996). In addition, HSP27 promotes cell survival by preventing oxidative stress (Mehlen et al., 1996a), resisting heat shock (Lavoie et al., 1993a), and resisting the toxic effects of anticancer chemicals (Huot et al., 1991), metabolic 
poisons (Wu and Welsh, 1996), and cytokines (Mehlen et al., 1995). HSP27 expression has been shown, moreover, to suppress apoptosis after tumor necrosis factor $\alpha(\mathrm{TNF} \alpha)$ or staurosporine treatment in mouse fibrosarcoma cells (Mehlen et al., 1996b; Samali and Cotter, 1996). Given these diverse but important actions of HSP27, we have now examined the pattern of regulation in primary sensory neurons during development and after injury.

\section{MATERIALS AND METHODS}

Surgical procedures. Adult male Sprague Dawley rats (200-300 gm) were anesthetized with halothane (induction, $4 \%$; maintenance, $2.5 \%$ ). The left sciatic nerve was exposed at the midthigh level and ligated before being sectioned immediately distal to the ligation. The wound was sutured in two layers, and the animals were allowed to recover. Section of the L4 and L5 dorsal roots was performed as described previously (Chong et al., 1994), and the animals were killed under terminal pentobarbital anesthesia $(200 \mathrm{mg} / \mathrm{kg}$, i.p.) after $2 \mathrm{~d}$. Inflammation was produced by intraplantar injection of $100 \mu \mathrm{l}$ of complete Freund's adjuvant (CFA) (Sigma, St. Louis, MO) into the left hindpaw under halothane anesthesia (Woolf et al., 1996). All procedures were performed in accordance with the British Home Office Animal Inspectorate and Massachusetts General Hospital Animal Research regulations.

Tissue preparation. Animals were terminally anesthetized with 200 $\mathrm{mg} / \mathrm{kg}$ sodium pentobarbitone (Duphar) and exsanguinated. The sciatic nerve was exposed and followed up to the L4 and L5 DRGs. The dorsal roots were then traced up to the dorsal root entry zones of the spinal cord, and the L4 and L5 spinal segments were identified. The L4 and L5 DRGs and the L4/L5 lumbar spinal cord were then rapidly removed, and RNA was extracted for Northern analysis or the tissue was frozen for in situ hybridization (see below). Experimental tissue was taken from the side ipsilateral to the injury only, whereas material from naive animals was removed from both sides.

For immunohistochemistry, animals were terminally anesthetized and perfused transcardially with $200 \mathrm{ml}$ of saline, followed by $750 \mathrm{ml}$ of $4 \%$ paraformaldehyde in $0.1 \mathrm{M}$ phosphate buffer, $\mathrm{pH}$ 7.4. Dissected tissue (from DRGs, spinal cord, and sciatic nerve proximal to the lesion) was post-fixed for $6 \mathrm{hr}$ and immersed in 20-30\% sucrose in $0.1 \mathrm{M}$ phosphate buffer, $\mathrm{pH} 7.4$, at $4^{\circ} \mathrm{C}$ overnight.

For a developmental analysis, time-mated pregnant Sprague Dawley rats were terminally anesthetized (as above); litters aged embryonic day 15 (E15) $(n=12)$ were removed; and all lumbar DRGs were dissected and used for immediate RNA extraction. Rats aged postnatal day 0 (P0) $(n=6), \mathrm{P} 7(n=5), \mathrm{P} 14(n=5)$, and P21 $(n=4)$ were terminally anesthetized; DRGs and dorsal horns were dissected; and RNA was extracted.

Subtractive hybridization. Genes induced or markedly upregulated at the mRNA level in the rat dorsal root ganglion after sciatic nerve transection were isolated by a PCR-based subtractive hybridization protocol (Brady et al., 1995). In brief, first-strand cDNAs ranging in size from 100 to 600 bases representing the distal $3^{\prime}$ ends of the original transcripts were produced by a limited reverse transcription step (Brady et al., 1990) using $250 \mathrm{ng}$ of total rat dorsal root ganglion RNA, $80 \mathrm{ng} / \mathrm{ml}$ pd(T)12-18 (Pharmacia, Piscataway, NJ), and a $12.5 \mathrm{~mm}$ concentration of each dNTP in reverse transcription buffer (in mm: 50 Tris- $\mathrm{HCl}, \mathrm{pH} 8.5$, $75 \mathrm{KCl}$, and $3 \mathrm{MgCl}_{2}$ ). After $3 \mathrm{~min}$ at $65^{\circ} \mathrm{C}, 200 \mathrm{U}$ of Moloney murine leukemia virus reverse transcriptase and $40 \mathrm{U}$ of ribonuclease inhibitor (Promega, Madison, WI) were added, and the reactions were incubated for $15 \mathrm{~min}$ at $37^{\circ} \mathrm{C}$. A poly(A) tail was added to the single-stranded cDNA using terminal transferase and dATP. Each tailed cDNA population was amplified by PCR using a single primer, either the NotIdT primer (naive

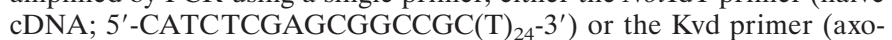
tomy cDNA; 5'-GGTAACTAATACGACTC $(\mathrm{T})_{24} \mathbf{3}^{\prime}$ ). PCR reactions were performed in a total volume of $100 \mu \mathrm{l}$ containing $1 \mu \mathrm{l}$ of poly(A)tailed cDNA, $10 \mu \mathrm{l}$ of $10 \times \mathrm{Mg}^{2+}$-free Taq polymerase buffer (Promega), $6 \mu \mathrm{l}$ of $25 \mathrm{mM} \mathrm{MgCl}_{2}$, a $25 \mathrm{~mm}$ concentration of each dNTP, $1 \mu \mathrm{g}$ of primer, and $4 \mathrm{U}$ of $\mathrm{Taq}$ polymerase (Promega). PCR amplification conditions were 30 cycles of $30 \mathrm{sec}$ at $94^{\circ} \mathrm{C}, 30 \mathrm{sec}$ at $45^{\circ} \mathrm{C}$, and $30 \mathrm{sec}$ at $72^{\circ} \mathrm{C}$. A 40 -fold excess of naive cDNA $(4 \mu \mathrm{g})$ was photobiotinylated (Barr and Emanuel, 1990) and mixed with $100 \mathrm{ng}$ of unlabeled axotomy cDNA. This mixture was denatured and hybridized at $68^{\circ} \mathrm{C}$ for $72 \mathrm{hr}$. The cDNA hybrid molecules incorporating biotinylated naive cDNA were removed with the addition of streptavidin and phenol-chloroform extraction. The

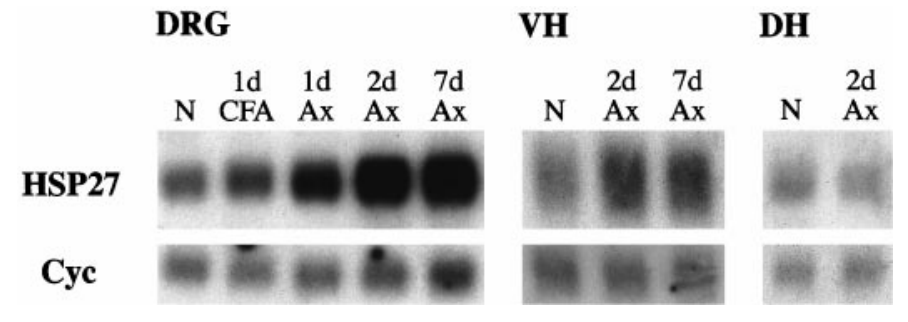

Figure 1. Northern blots for HSP27 and cyclophilin mRNA in L4 and L5 dorsal root ganglia $(D R G)$, ventral horn $(V H)$, and dorsal horn $(D H)$. The DRG lanes contain mRNA ( $n=4$ animals) from naive unoperated animals $(N)$, animals $1 \mathrm{~d}$ after CFA injection (1d CFA), and animals 1,2 , and $7 \mathrm{~d}$ after sciatic axotomy $(A x)$. VH lanes contain mRNA from L4 and L5 ventral horn segments of the spinal cord ( $n=3$ animals) from naive unoperated animals $(N)$ and animals 2 and $7 \mathrm{~d}$ after sciatic cut axotomy $(A x)$. DH lanes contain mRNA from L4 and L5 dorsal horn segments of the spinal cord ( $n=4$ animals) from naive unoperated animals $(N)$ and animals $2 \mathrm{~d}$ after sciatic cut axotomy $(2 d A x)$. Note the absence of HSP27 mRNA upregulation within the DH $2 \mathrm{~d}$ after sciatic nerve axotomy. All experimental material was taken from the same side as the lesion.

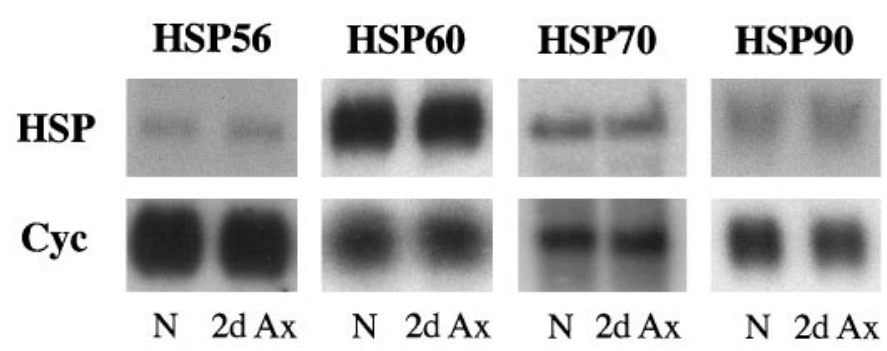

Figure 2. Northern blots for HSP56, HSP60, HSP70, HSP90, and cyclophilin mRNA in the L4 and L5 dorsal root ganglia ( $n=4$ animals). Lanes contain mRNA from naive unoperated animals $(N)$ and animals $2 \mathrm{~d}$ after sciatic axotomy $(2 d A x)$. Note that in contrast to HSP27 regulation, none of these HSP mRNA are upregulated within the DRG $2 \mathrm{~d}$ after sciatic nerve axotomy. HSP56, HSP60, HSP70, and HSP90 mRNA were also not regulated 1 and $7 \mathrm{~d}$ after sciatic cut or $1 \mathrm{~d}$ after CFA injection in the DRG or in the dorsal horn.

unlabeled cDNA remaining in the aqueous phase was precipitated, resuspended in $\mathrm{H}_{2} \mathrm{O}$, and reamplified with the Kvd primer, producing a first-round subtraction product (S1). A $100 \mathrm{ng}$ sample of S1 cDNA was used in a second round of subtractive hybridization against $4 \mu \mathrm{g}$ of original biotinylated naive cDNA, producing a second-round subtraction product. A third round of subtraction was performed in an identical manner, yielding the final subtraction cDNA product (S3).

$c D N A$ library screening. To isolate cDNA clones represented in the third subtraction product, $5 \times 10^{5}$ clones from a $\lambda$ Zap II rat DRG cDNA library were plated on four $20 \times 20 \mathrm{~cm}$ dishes. The plaques were blotted onto Hybond $\mathrm{N}+$ nylon filters (Amersham, Arlington Heights, IL), and the filters were hybridized with the third subtraction product. A $100 \mathrm{ng}$ sample of S3 cDNA was radiolabeled by incorporation of $50 \mu \mathrm{Ci}$ of ${ }^{32} \mathrm{P}[\mathrm{dCTP}]$ using standard cDNA-labeling conditions. Radiolabeled cDNA was separated from unincorporated nucleotides on Sephadex G-50 columns. Filters were prehybridized and hybridized in a solution containing $6 \times$ SSC, $10 \%$ dextran sulfate, $0.5 \%$ SDS, $5 \times$ Denhardt's solution (100× Denhardt's solution: $0.2 \%$ BSA, $0.2 \%$ ficoll, and $0.2 \%$ polyvinylpyrrolidone), and $100 \mu \mathrm{g} / \mathrm{ml}$ sheared herring sperm DNA at $65^{\circ} \mathrm{C}$. Filters were washed to a final stringency of $0.2 \times$ SSC and $0.1 \%$ SDS at $65^{\circ} \mathrm{C}$.

Northern blot analysis. Total cellular RNA was extracted from homogenized tissue samples by acid-phenol extraction according to Chomczynski and Sacchi (1987). RNA (10 $\mu \mathrm{g} / \mathrm{sample})$ was separated on $1.5 \%$ formaldehyde-agarose gels and blotted onto Hybond $\mathrm{N}+$ nylon membranes using standard conditions. Filters were prehybridized and hybridized in a solution containing $50 \%$ formamide, $5 \times$ SSC, $5 \times$ Denhardt's solution, $1 \%$ SDS, and $100 \mu \mathrm{g} / \mathrm{ml}$ sheared herring sperm DNA at $42^{\circ} \mathrm{C}$. The filters were washed in $0.1 \times \mathrm{SSC}$ and $0.1 \% \mathrm{SDS}$ at $42^{\circ} \mathrm{C}$. The HSP $27 \mathrm{cDNA}$ probe was derived from an 800 bp insert in pBluescript $\mathrm{KS}+$ and isolated as described above. The 


\section{Development}

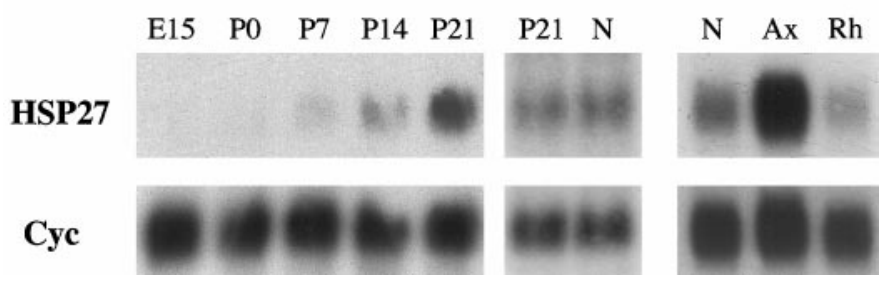

Figure 3. Northern blots for HSP27 and cyclophilin mRNA in L4 and L5 dorsal root ganglia. Development, At E15, no expression is detected. From P0 to P21, HSP27 mRNA gradually increases to levels approximately equal to those seen in the adult $(N)$. Note that the Northern blot for the embryonic and neonatal RNA (E15 to P21) has been exposed for several weeks compared with several days for those of adult RNA (P21 and $N)$. Rhizotomy, Lanes contain mRNA from naive unoperated animals $(N)$, animals $2 \mathrm{~d}$ after peripheral axotomy $(A x)$, and animals $2 \mathrm{~d}$ after dorsal root section $(R h)$. Note the absence of regulation of HSP27 after dorsal root section in contrast to that seen after axotomy of the peripheral nerve. The slight decrease of HSP27 levels in the $R h$ lane relative to the $N$ lane is attributable to loading differences on the original Northern blot (see $C y c)$.

HSP56 probe was obtained from a $2 \mathrm{~kb}$ rabbit cDNA (kindly donated by David Latchman, University College London, London, England). Other probes used were derived by PCR from rat cDNA sequences (obtained from GenBank) and subsequently were cloned into the pGEM-T cloning vector (Promega). A $240 \mathrm{bp}$ rat cyclophilin PCR product was produced using the following primers: Cyc1, 5'-TTGGGTCGCGTCTGCTTCGA-3'; and Cyc2, 5'-GCCAGGACCTGTATGCTTCA-3'. A 295 bp rat HSP60 PCR product was produced with the following primers: HSP60A, 5'-GAACTGT GGCAGGAAGCTCAA-3'; and HSP60B, 5'-GCGCTACAGTCCTG ATGCTAA-3'. A rat HSP70 PCR product of 443 bp was produced using the following primers: HSP70A, 5'-CTAACACGCTGGCTGAGAAA-3'; and HSP70B, 5'-GGGTGGC AGTGCTGAGGTGTT-3'. A 348 bp rat HSP90 PCR product was produced using the following primers: HSP90A, 5'-GTCTTCTCTCGCTTCTCACTT-3'; and HSP90B, 5'-CTATCTGT GGGAGGGGATCTT-3'. A $50 \mathrm{ng}$ sample of each probe was radiolabeled as above.

At least two independent Northern blots obtained from RNA extracted from a different pool of animals were used for each observation.

In situ hybridization. All in situ hybridization was performed using digoxygenin-labeled riboprobes. Plasmid containing an 800 bp HSP27 cDNA insert (867 bp) was amplified and linearized with $\mathrm{XhoI}$ or $\mathrm{Xba \textrm {I }}$ restriction enzymes. In vitro transcription was performed at $37^{\circ} \mathrm{C}$ for $2 \mathrm{hr}$ using $1 \mu \mathrm{g}$ of linearized template, $2 \mu \mathrm{l}$ of transcription buffer (Boehringer Mannheim, Indianapolis, IN), $2 \mu \mathrm{l}$ of digoxygenin-labeling mix (Boehringer Mannheim), and $2 \mu \mathrm{l}$ of RNA polymerase [T7 for XbaI (antisense) and T3 for XhoI (sense) linearized templates; Boehringer Mannheim], and made up to $20 \mu \mathrm{l}$ with RNase-free $\mathrm{H}_{2} \mathrm{O}$. The reaction was stopped with $1.5 \mu \mathrm{l}$ of $0.2 \mathrm{M}$ EDTA and $2.5 \mu \mathrm{l}$ of $4 \mathrm{M} \mathrm{LiCl}$, and $75 \mu \mathrm{l}$ of $100 \%$ ethanol was added. RNA was precipitated and redissolved in $100 \mu \mathrm{l}$ of RNase-free $\mathrm{H}_{2} \mathrm{O}$.

Fresh frozen $30 \mu \mathrm{m}$ DRG sections were mounted onto slides and air-dried. Slides were placed in 4\% paraformaldehyde in 0.1 м PBS for 10 min, washed in $0.1 \mathrm{M}$ PBS three times, acetylated for $10 \mathrm{~min}$, and permeabilized in $1 \%$ Triton X-100 (Sigma) for $30 \mathrm{~min}$. They were washed again in $0.1 \mathrm{M}$ PBS three times, and $1 \mathrm{ml}$ of prehybridization buffer was put on each slide for $6 \mathrm{hr}$ in a humidified chamber. Sections were then incubated in hybridization buffer (probe concentration, $250 \mathrm{ng} / \mathrm{ml}$ ) overnight at $60^{\circ} \mathrm{C}$ and washed in decreasing concentrations of SSC ( 5 to $\left.0.1 \times\right)$ for $1 \mathrm{hr}$. Sections were washed in $0.1 \mathrm{M}$ Tris, $\mathrm{pH} 7.5$, and $0.15 \mathrm{M} \mathrm{NaCl}$ for $5 \mathrm{~min}$ and then prehybridized in blocking buffer for $1 \mathrm{hr}$ before being incubated overnight at $4^{\circ} \mathrm{C}$ in blocking buffer with anti-digoxygenin antibody (1:500) (Boehringer Mannheim). They were then washed again before staining was visualized in $75 \mu \mathrm{g} / \mathrm{ml}$ nitro blue tetrazolium, 50 $\mu \mathrm{g} / \mathrm{ml}$ 5-bromo-4-chloro-3-indolyl phosphate, and $0.24 \mathrm{mg} / \mathrm{ml}$ levamisole (Sigma) in Tris buffer, $\mathrm{pH}$ 9.5. Reaction was stopped with Tris-EDTA, and sections were washed in deionized $\mathrm{H}_{2} \mathrm{O}$ and air-dried. Slides were coverslipped using Kaiser's mountant.

To estimate in vivo cell numbers and construct histograms free of size and shape biases, HSP27 mRNA-positive cells were identified in a physical dissector paradigm (Pover et al., 1993). To do this, pairs of sections (look-up and reference) at standard $(k)$ intervals through the ganglion beginning at a random number between 1 and $k$ were obtained. Those cells seen in each reference, but not in the look-up sections, were identified. The cells were then drawn, and their areas were calculated (in square micrometers).

The numbers of DRG cells in vitro showing HSP27 immunoreactivity were estimated in adult rats $(n=3) 2 \mathrm{hr}$ after plating the cells by counting every cell in 10 randomly selected areas comprising $30 \%$ of each coverslip. Numbers are expressed as mean percentage of positively stained cells.

Western blots. Pooled L4 and L5 DRG from naive and axotomized animals were boiled for $10 \mathrm{~min}$ in $3 \%$ SDS, and then equal volumes of 0.3 M sucrose were added. Ganglia were homogenized in the presence of 100 mM phenylmethylsulfonylfluoride (Sigma) using a hand-held pellet pestle (Fisher Scientific, Houston, TX) and spun at $14,000 \mathrm{rpm}$ for $10 \mathrm{~min}$. Protein quantification was performed by the bicinchoninic acid method using the BCA assay kit (Pierce, Rockford, IL). Protein samples $(20 \mu \mathrm{g})$ were electrophoresed on SDS-acrylamide gels and transferred to an Immobilon-P membrane ( $0.45 \mu \mathrm{m}$; Millipore, Bedford, MA). Membranes were blocked with $5 \%$ nonfat dried milk and $0.05 \%$ Tween 20 in PBS (TPBS) for $1 \mathrm{hr}$ at room temperature. Primary incubation was performed with anti-HSP 27 (goat polyclonal IgG; Santa Cruz Biotechnology, Santa Cruz, CA) diluted 1:500 in 3\% dried milk and 0.05\% TPBS for $1 \mathrm{hr}$ at room temperature. After washing with $3 \%$ dried milk, $0.05 \%$ TBPS membranes were incubated with peroxidase-labeled anti-goat IgG (Vector Laboratories, Burlingame, CA) in 3\% dried milk and $0.05 \%$ TPBS for $1 \mathrm{hr}$ at room temperature. Membranes were washed with $0.05 \%$ TPBS and $1 \times$ PBS and visualized on Hyperfilm ECL (Amersham) using the Renaissance chemiluminescent detection assay (New England Biolabs, Beverly, MA).

Immunocytochemistry. Fifty-micrometer sections were washed in $0.1 \mathrm{M}$ PBS and then washed in $0.8 \%$ bovine serum albumin (BSA), $0.25 \%$ Triton X-100 (Sigma), and 5\% normal goat serum (NGS) in $0.1 \mathrm{~m} \mathrm{PBS}$ for $1 \mathrm{hr}$. After three $0.1 \mathrm{M}$ PBS washes, sections were incubated in goat anti-HSP27 antibody (1:500-1:2000; Santa Cruz) in 0.8\% BSA, $0.25 \%$ Triton X-100, and $1 \%$ NGS in $0.1 \mathrm{M} \mathrm{PBS}$ at $4^{\circ} \mathrm{C}$ for $48 \mathrm{hr}$. After further washes in $0.1 \mathrm{M}$ PBS, sections were left in $2^{\circ} \mathrm{C}$ antibody (rabbit anti-goat; 1:200 dilution) for $2 \mathrm{hr}$ at room temperature and then washed three times with PBS and visualized with the indirect HRP-DAB reaction using a standard Vectastain kit (Vector). Sections were then washed in $\mathrm{H}_{2} \mathrm{O}$, mounted, and coverslipped using DPX (Fisher Scientific).

$D R G$ neuron culture. Animals were terminally anesthetized and exsanguinated as described above. Lumbar DRGs were removed aseptically and digested in $0.125 \%$ collagenase (Boehringer Mannheim) for $3 \mathrm{hr}$. Cells were then mechanically dissociated using a flame-polished Pasteur pipette. The cell suspension was spun at $1000 \mathrm{rpm}$ through $15 \%$ BSA (Sigma), and the cell pellet was resuspended in F-12 growth medium (Hu-Tsai et al., 1994) with 4\% Ultroser-G (Life Technologies, Gaithersburg, MD). Cells were plated onto polyornithine-laminin-coated $22 \mathrm{~mm}$ glass coverslips, $10^{4}$ cells per coverslip, and grown in $35 \mathrm{~mm}$ dishes at $36.5^{\circ} \mathrm{C}$ with $95 \%$ air and $5 \%$ carbon dioxide.

\section{RESULTS}

\section{Characterization of HSP27 as a nerve injury-regulated gene}

A clone, isolated by subtractive hybridization of axotomized minus naive DRG cDNA and subsequent cDNA DRG library screening, was identified by sequencing as rat HSP27 (Uoshima et al., 1993). To confirm that HSP27 mRNA levels respond to peripheral axotomy, experiments were performed that showed that sciatic nerve section substantially elevated HSP27 mRNA in L4 and L5 dorsal root ganglia ipsilateral to the injury. The elevation was marked at $24 \mathrm{hr}$, with a ninefold increase at $48 \mathrm{hr}$ after lesion, and this was maintained 1 week after injury (Fig. 1). In contrast to nerve section, inflammation induced by intraplantar injection of CFA into the hindpaw (Woolf et al., 1996) produced a much smaller increase in HSP27 mRNA levels at $1 \mathrm{~d}$ (less than twofold) (Fig. 1), which returned to basal levels by $5 \mathrm{~d}$ after inflammation. HSP27 mRNA levels in the dorsal horn remained unchanged $2 \mathrm{~d}$ and 1 week after sciatic nerve section (Fig. 1) and 

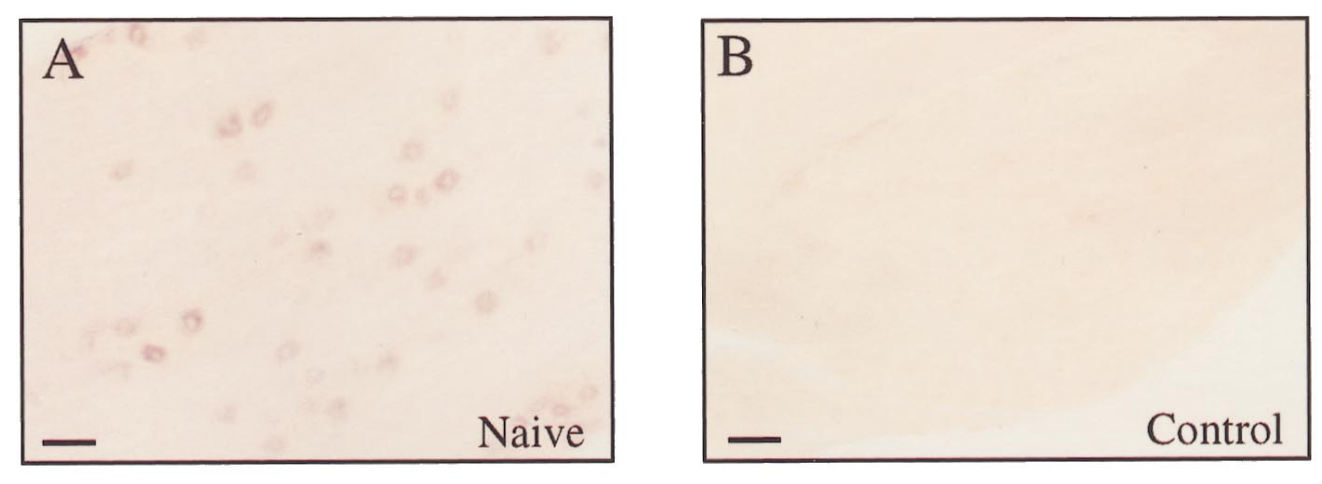

Figure 4. Photomicrographs of 30 $\mu \mathrm{m}$ sections showing HSP27 mRNA expression in the L4 DRG of naive animals $(A)$. Note faint staining in cells across the DRG, many of which are medium and large in size. $B, \mathrm{~A}$ sense strand HSP27-probed DRG section. $C$, Forty-eight hours after sciatic nerve section, intensity of HSP27 mRNA staining is dramatically increased, as is the number of cells stained. $D$, One week after axotomy, staining is still increased. High-power photomicrographs of HSP27 staining in naive ganglia $(E)$ and $48 \mathrm{hr}$ after axotomy $(F)$ show clearly the increase in the intensity of stain. Along with the medium- and large-sized DRG neurons that constitutively express HSP27 (arrowheads), axotomy induces de novo expression in small DRG neurons (arrows). Scale bars, $100 \mu \mathrm{m}$.
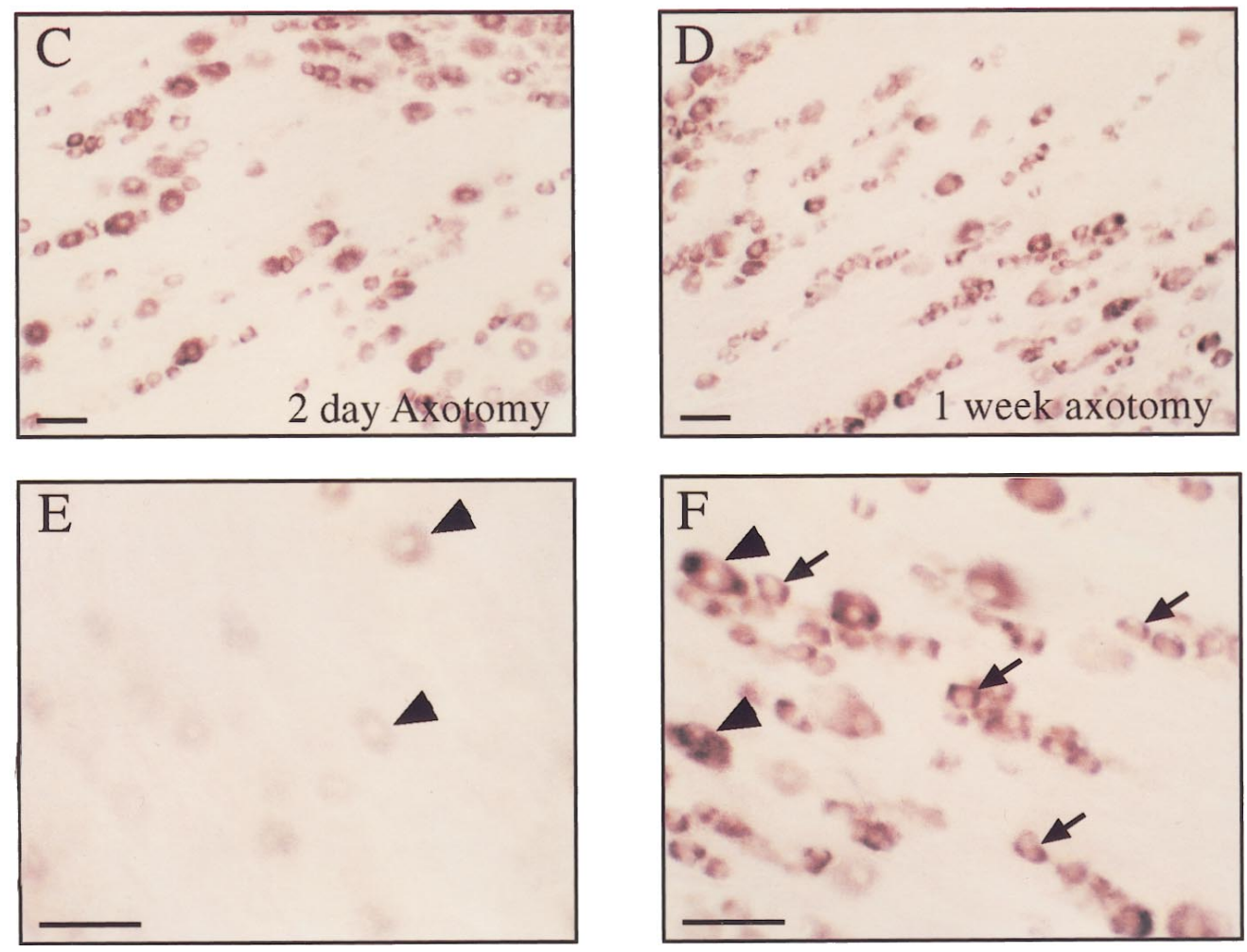

after CFA injection (data not shown). An upregulation of HSP27 mRNA was also detected in the ipsilateral ventral quadrant of the spinal cord $2 \mathrm{~d}$ after sciatic nerve injury and remained upregulated at $7 \mathrm{~d}$ (Fig. 1).

Expression of mRNAs for HSP56, HSP60, HSP70, and HSP90 were also analyzed, but none were regulated within the DRG or dorsal horn at 1,2 , or $7 \mathrm{~d}$ after sciatic cut or $1 \mathrm{~d}$ after CFA injection (Fig. 2).

\section{Central axotomy does not upregulate HSP27 mRNA}

Primary sensory neurons possess a peripheral and a central axon. Injury to the central axon generally fails to induce the same pattern of changes in the phenotype of sensory neurons that a peripheral axotomy does (Chong et al., 1994), nor does it elicit as vigorous a regenerative response (Chong et al., 1996). Section of the L4 and L5 dorsal roots did not result in an upregulation of HSP27 mRNA levels in their respective ganglia $2 \mathrm{~d}$ after injury, in contrast to the substantial increase seen at the same period after peripheral axotomy (Fig. 3).

\section{HSP27 mRNA regulation during development}

Many genes reexpressed after peripheral nerve injury are developmentally regulated and present at high levels in the embryo but are downregulated on innervation of the target (Skene, 1989). At E15, HSP27 mRNA expression was not detectable within the DRG. At birth, HSP27 mRNA expression was just detectable, but by P21, levels rose to an amount approaching that seen in the adult DRG (Fig. 3).

\section{Cellular localization of HSP27 mRNA within the DRG before and after peripheral axotomy}

In situ hybridization for HSP27 mRNA in L4 and L5 DRGs from naive animals showed low levels of constitutive expression, predominantly in medium and large neurons (Figs. 4A, 5). Sense controls revealed no staining (Fig. 4B). HSP27 mRNA expression in the DRG $48 \mathrm{hr}$ after sciatic nerve section increased both in terms of the number of cells stained and the intensity of stain within each positive cell (Fig. $4 C$ ). This pattern of staining was maintained at $7 \mathrm{~d}$ (Fig. $4 D$ ). At $48 \mathrm{hr}$, not only was the staining much darker in the medium- and large-sized cells, but a population of small cells that were negative for HSP27 mRNA in the DRGs of naive animals (Fig. $4 E$ ) were positive after axotomy (Fig. $4 F$ ).

Quantitative stereological analysis found $2867 \pm 691$ (SE) HSP27 mRNA-positive neurons in the L4 DRG in naive animals 


\section{Size frequency distribution of HSP27 +ve cells}

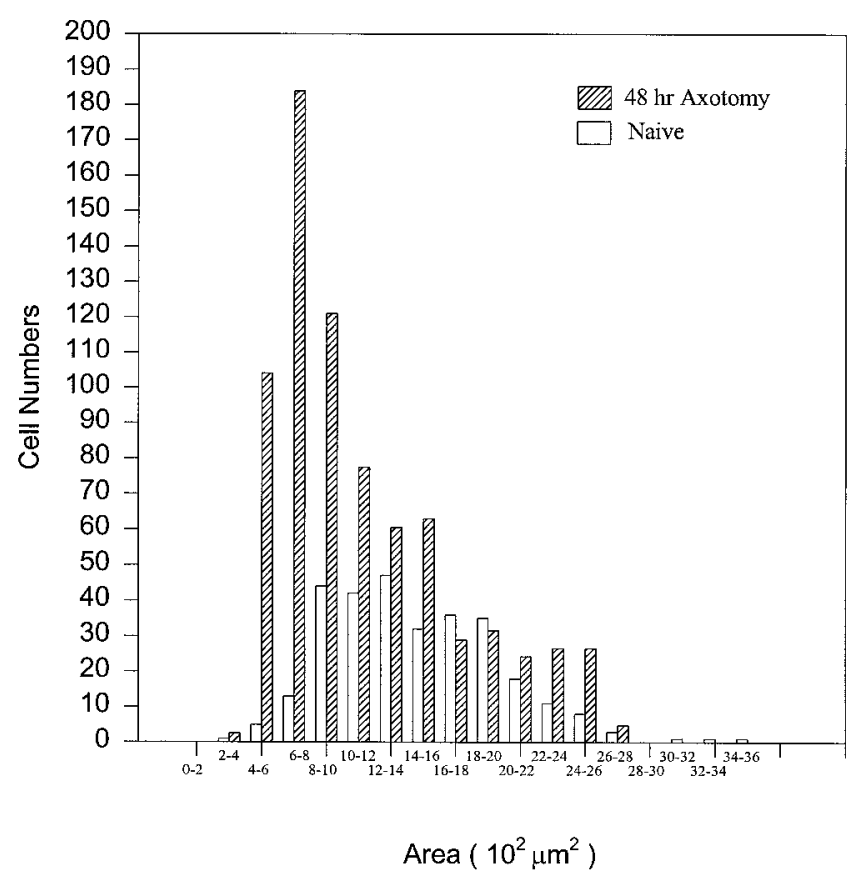

Figure 5. A size frequency histogram of HSP27 mRNA expression in the naive animal and $48 \mathrm{hr}$ after sciatic nerve section. The size frequency histogram shifts to the left after axotomy, reflecting a novel expression of message in smaller cells within the DRG, but there is also a relative increase in large neurons, as well.

$(n=3)$, the majority of which ranged between 400 and $2500 \mu \mathrm{m}^{2}$ in the profile area. Two days after sciatic nerve section, approximately two and a half times the number of cells stained for HSP27 mRNA compared with normal [7012 \pm 725 (SE); $n=3$; $p<0.05]$, the majority of these having profile areas ranging between 400 and $1500 \mu \mathrm{m}^{2}$. The size frequency histogram in Figure 5 shows that a new subpopulation of HSP27 mRNApositive cells with smaller profile areas appeared after nerve injury and that the proportion of large DRG HSP27 mRNApositive cells increased. The distribution of the labeled cells after axotomy in Figure 5 is very similar to that produced after labeling DRG cells with axons in the sciatic nerve (Woolf et al., 1995), indicating that axotomized DRG cells representative of the entire population of sciatic DRG neurons, based on size, upregulate HSP27. Because the sciatic nerve only represents $\sim 60-70 \%$ of the L4 DRG (Woolf et al., 1995), the unlabeled cells are likely to be predominantly, if not exclusively, nonaxotomized neurons.

\section{HSP27 protein levels after peripheral axotomy}

Western blot analysis of naive and ipsilateral L4 and L5 DRG after axotomy showed a marked increase in HSP27 protein levels, with HSP27 protein increasing over a similar time scale to that of the mRNA (Fig. 6A).

Immunohistochemical analyses of the L4 and L5 DRGs for HSP27 immunoreactivity (HSP27-IR) revealed a pattern of staining similar to that for in situ hybridization. Cells constitutively positive for HSP27-IR in DRGs from naive animals were predominantly medium-sized, with some large-sized (Fig. 6B), but after nerve injury HSP27-IR was seen in small-, medium-, and large-sized cells (Fig. 6C). HSP27-IR could also be seen after
A
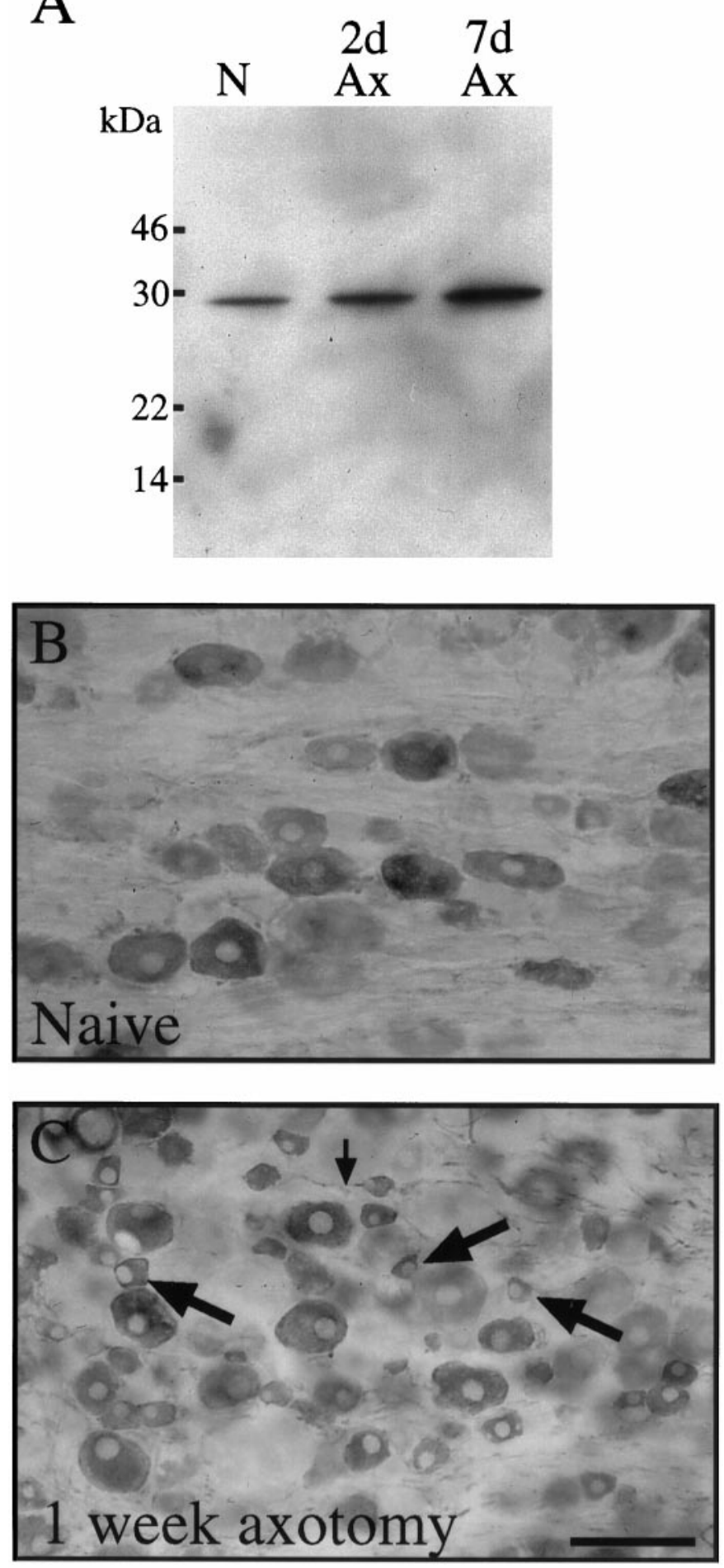

Figure 6. A, Western blot analysis of DRG for HSP27 protein levels. Lanes contain $20 \mu \mathrm{g}$ of L4 and L5 DRG protein pooled from naive unoperated animals $(N)$ and animals 2 and $7 \mathrm{~d}$ after sciatic axotomy $(A x)$. Note that the anti-HSP27 antibody recognizes a single band of $\sim 28 \mathrm{kDa}$ Positions of molecular weight markers are indicated. $B, C$, Photomicrographs of $50 \mu \mathrm{m}$ sections showing HSP27 immunoreactivity in the L4 DRG. In naive animals $(B)$, staining is observed in some DRG neurons, most of which are medium and large in size. Seven days after sciatic nerve section $(C)$, more cells are stained, and consistent with changes seen at the mRNA level, many small cells are positive for HSP27 after axotomy (arrows). Note that HSP27 staining is also observed in the stem axons leaving DRG cell bodies (small arrow). Scale bar, $100 \mu \mathrm{m}$. 
Figure 7. Photomicrographs of $50 \mu \mathrm{m}$ sections showing HSP27 immunoreactivity in the dorsal horn of the $\mathrm{L} 5$ segment of spinal cord. In the naive animal $(A)$, fibers are observed in laminae I, III, and IV, in which A-fiber central axon collaterals are known to terminate. Staining is also observed in the dorsal columns. Lamina II is devoid of staining (arrow). B, One week after sciatic nerve section, there is increased HSP27 staining predominantly in the superficial laminae (I and II) of the dorsal horn (arrow). C, Two weeks after axotomy, increased staining is observed in laminae III and IV, as well as in the superficial laminae. Note that the dorsal columns are also densely stained. $D$, Two months later, HSP27 immunostaining remains in all laminae of the dorsal horn. The dorsal columns ipsilaterally remain heavily stained (compared with contralateral). Scale bars (in $A-D$ ), $200 \mu \mathrm{m}$. E, Photomicrograph of $50 \mu \mathrm{m}$ section of sciatic nerve proximal to a ligature 1 week previously. Note that HSP27 has accumulated proximal to the ligature, showing that the protein is anterogradely transported down axons to the periphery. Inset, HSP27 staining in the normal nerve. Scale bar, $1 \mathrm{~mm} . F$, HSP27 staining in a spinal cord section 1 week after sciatic nerve section. Along with increased staining in the superficial laminae of the dorsal horn, HSP27 is also upregulated in motor neuron cell bodies of the ventral horn (arrows). Scale bar, $200 \mu \mathrm{m}$.
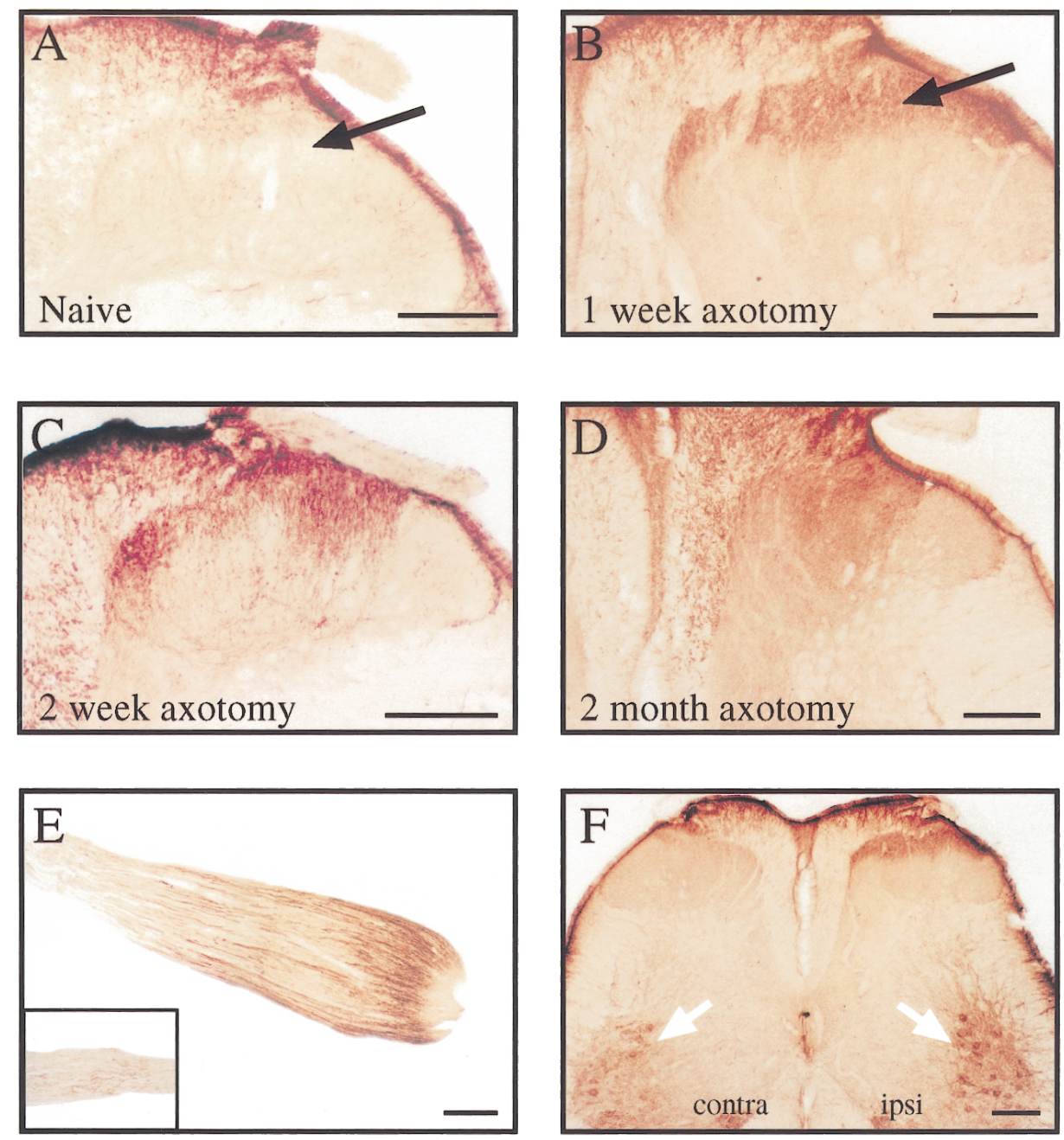

axotomy in axons leaving the cell bodies of DRG neurons (Fig. $6 C$ ). Cellular staining was most intense at $7 \mathrm{~d}$ after the sciatic lesion but was maintained at high levels at 2 weeks (data not shown).

\section{HSP27 is transported to the central and peripheral terminals of injured sensory neurons}

The dorsal horn of the spinal cord from naive animals revealed light HSP27 staining of fibers terminating in laminae I, III, and IV, areas devoted to A-fiber terminals, but not in lamina II, an area receiving $\mathrm{C}$-fiber terminals (Fig. $7 A$ ). One week after peripheral axotomy, dense staining was observed in laminae I and II of the dorsal horn (Fig. 7B). After 2 weeks, intensely labeled fibers could be seen in lamina III, as well as in the superficial laminae, and in addition many stem axons ascending in the dorsal columns were now more positive (Fig. 7C). Two months after peripheral nerve section and ligation, heavy staining of HSP27 was observed in primary afferent central axons in laminae I, II, III, and IV and in the dorsal columns (Fig. 7D).

When the sciatic nerve was stained in naive animals, only faintly stained HSP27-positive fibers were observed (Fig. 7E, inset). One week after nerve section and ligation, HSP27-IR accumulated proximal to the ligature (Fig. $7 E$ ), showing that it is anterogradely transported along peripheral, as well as central, axons.
In animals subjected to sciatic crush lesions, in which regeneration with reinnervation of peripheral targets occurs between 2 and 6 weeks, the pattern of increased HSP27 labeling in the dorsal horn was similar to that found in animals in which the nerve was cut and ligated (data not shown). At 8 weeks after lesion, an increased level of staining was still detectable on the side of the spinal cord ipsilateral to the nerve crush, although this was less than that seen in animals with ligation injuries at this time point.

The change in HSP27-IR was not restricted to sensory neurons. Staining within the sciatic nerve motor pool in the ventral horn of the L4 and L5 segments also increased 1 week after sciatic nerve section (Fig. $7 F$ ), and this was still observable at 2 months (data not shown).

\section{HSP27 distribution in cultured sensory neurons}

When freshly dissociated adult DRGs were stained $1 \mathrm{hr}$ after plating, only a subpopulation of the neurons were HSP27immunoreactive $(16.4 \pm 1.6 \% ; n=735)$ (Fig. $8 A$ ), a finding that is consistent with the levels of constitutive expression detected in naive animals in vivo (Fig. $4 A$ ). However, when the cells were stained after $24 \mathrm{hr}$ in culture, all DRG neurons (large, medium, and small) were HSP27-IR (>1000 cells surveyed) (Fig. 8B). In those cells with neurites, HSP27 staining was seen along the entire length of the cell, including the growth cone (Fig. $8 C, D$ ). 

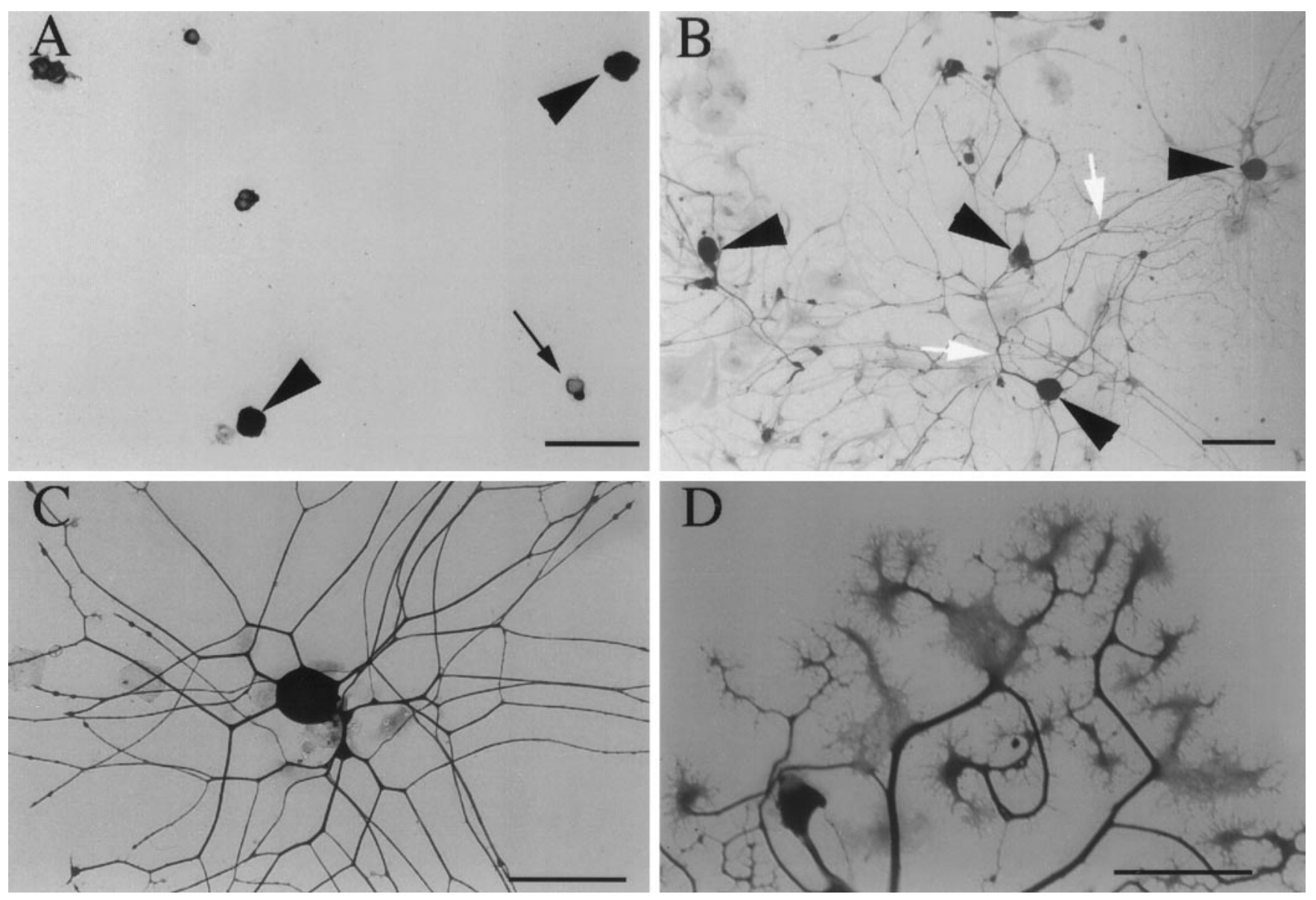

Figure 8. HSP27 immunoreactivity in dissociated adult primary DRG cultures. $A$, One hour after plating the cells. Despite some cells being intensely positive (arrowheads), other neurons are almost completely negative (arrow). B, After $24 \mathrm{hr}$, all dissociated neurons are positively stained for HSP27 (arrowheads). Note that staining is observed down the entire length of the neurites (white arrows and $C$ ). Scale bars (in $A-C$ ), $100 \mu \mathrm{m}$. $D$, HSP27 staining was also observed in growth cones. Scale bar, $30 \mu \mathrm{m}$.

\section{DISCUSSION}

\section{The axon response}

Peripheral nerve injury initiates a cascade of early, intermediate, and late alterations in injured sensory and motor neurons. Early changes are attributable to ion fluxes at the injured membrane that initiate an injury discharge (Wall and Gutnick, 1974). Later changes are the consequences of retrograde signals transported to the cell body (DiStefano et al., 1992). These signals, which result from both the loss of constitutive target-derived trophic factors and the introduction of novel signals at the site of injury, act to alter expression of a broad range of genes as part of the chromatolytic reaction or axon response. The axon response encompasses the immediate stressor effect of the injury, including altered metabolic demands, the induction of a regenerative response, and alterations in the functional performance of the injured neurons consequent on changes in the levels of transmitters, neuromodulators, ion channels, and receptors (Fitzgerald et al., 1985; Castro-Lopes et al., 1993; Devor et al., 1993; Verge et al., 1995).

\section{HSP27}

We now report that HSP27, a heat shock protein, is upregulated by peripheral axotomy in the adult rat. The heat shock proteins in general serve to protect cells against damage induced by physiological stress, including heat shock, oxidative stress, and noxious chemicals. Their expression in non-neuronal cells is strongly correlated with increased survival to such external challenges (Huot et al., 1991; Lavoie et al., 1993a; Wu and Welsh, 1996). Many HSPs are also constitutively expressed in normal cells, where they may play a role in cell growth, maintenance, and development (Marcuccilli and Miller, 1994).

HSP27 is a low molecular weight HSP, is highly homologous with the $\alpha$-crystallins (de Jong et al., 1997), and, like other HSPs, functions as a molecular chaperone, conserving the conformation of proteins (Jakob et al., 1993). It has, in addition, been shown to associate specifically with F-actin in a phosphorylation-dependent manner (Lavoie et al., 1995), which is postulated to affect cell motility and shape (Lavoie et al., 1993b; Mairesse et al., 1996). Recently, HSP27 has been shown to act as a specific cellular inhibitor of apoptosis in mouse fibrosarcoma (Mehlen et al., 1996b) and monoblastoid cells (Samali and Cotter, 1996). HSP27 also confers resistance to heat shock by stabilizing the cytoskeleton (Lavoie et al., 1995) and enhances survival in response to TNF $\alpha$-induced cell death by increasing glutathione levels (Mehlen et al., 1996a). Phosphorylation of the protein by specific kinases and dephosphorylation by phosphatases play a key role in its function (Lavoie et al., 1995), and these can be triggered by a number of factors, including $\mathrm{TNF} \alpha$, interleukin-1, bradykinin, and ATP (Saklatvala et al., 1991). The survival function may also be dependent on the HSP27 phosphorylation state. A recent study 
has shown that it is the unphosphorylated state that is protective against TNF $\alpha$ in NIH3T3 cells (Mehlen et al., 1997).

A constitutive expression of HSP27 in the nervous system has been demonstrated recently using immunohistochemistry and Western blots primarily in cranial and spinal motor nuclei, as well as in primary sensory neurons and their central processes (Plumier et al., 1997). Both ischemic and kainic acid lesions induce HSP27, but almost entirely in glia (Kato et al., 1994; Plumier et al., 1996).

\section{Changes in HSP27 expression after axotomy}

HSP27 was the only member of the HSP family tested (HSP56, HSP60, HSP70, and HSP90) that was upregulated in DRG neurons by peripheral axotomy. This indicates that this effect was not a simple result of an overall increase in transcription of stressrelated proteins in response to neuronal injury. Also, the data imply that whatever signal transduction cascade was responsible for the upregulation of HSP27, it is unlikely to include activation heat shock elements common to the promotor region of both HSP27 and other heat shock proteins such as HSP70. The change in HSP27 mRNA levels may of course be attributable to changes in mRNA stability. Further indications of the specificity of HSP27 regulation were the failure of central axotomy produced by sectioning the dorsal root to upregulate HSP27 and the minimal effects of peripheral inflammation, which has powerful effects on DRG gene expression (Leslie et al., 1995). Central axotomy differs from peripheral axotomy in that it disrupts contact with the central target but leaves growth factor support from the periphery intact. Inflammation, although changing the chemical environment of the peripheral terminal, also leaves contact between the peripheral axon and its target intact, implying that there is something specific to the disruption of this contact that results in the upregulation of HSP27. A selective response to injury of the peripheral and not the central axon also occurs for the growthassociated gene GAP-43 (Chong et al., 1994). HSP27 expression is, however, different from that of GAP-43 in two major ways. First, constitutive expression of GAP-43 is located within small DRG neurons (Verge et al., 1990; Woolf et al., 1990), whereas it is the medium- and large-sized DRG cells that constitutively express HSP27. Second, HSP27 levels are low during the active growth state of development with a progressive upregulation of HSP27 over the early postnatal period, which is different from the developmental regulation of growth-associated genes that are present at high levels during the active growth state in early development and then downregulated on establishment of contact with targets (Skene, 1989).

Although we have demonstrated an elevation in HSP27 mRNA and protein after peripheral nerve injury, it would be of considerable interest to establish the phosphorylation state of HSP27 in this situation, given the alterations in function associated with phosphorylation and dephosphorylation of this protein (Lavoie et al., 1995, Mehlen et al., 1997).

\section{HSP27 and regeneration of injured neurons}

Based on the actions of HSP27 in non-neuronal cells, an increased expression of the molecule may contribute to a number of different functions in injured sensory and motor neurons. One role may be an involvement of HSP27 in the regeneration that follows peripheral axotomy as a consequence of its involvement in actin filament dynamics. HSP27 has been proposed to act as an actin filament-capping protein, potentially either preventing or permitting actin filament synthesis depending on its phosphory- lation state (Lavoie et al., 1995). The distribution of HSP27 along axons in vivo and into the growth cones in vitro is compatible with a possible role in the growing tip of the axon. Against a general role for HSP27 in neurite outgrowth, axon guidance, or the establishment of synaptic connections is our finding that HSP27 is not present when axons are actively growing in early development. There is a possibility, however, that regeneration in the adult and growth in development occur by distinct processes.

\section{HSP27 and cell death in injured neurons}

Numerous studies have linked HSP27 upregulation with increased cell survival. Overexpression of HSP27, for example, correlates with resistance to the cytotoxicity produced by anticancer chemicals or metabolic poisons, including cadmium chloride, mercuric chloride, or sodium arsenite (Huot et al., 1991; Wu and Welsh, 1996). In human breast cancer cell lines and neuroblastoma cells, HSP27 expression correlates with growth and drug resistance. Recent studies have also shown that overexpression of HSP27 in murine fibrosarcoma cells suppresses the apoptotic response to Fas/APO-1, staurosporine (Mehlen et al., 1996b), actinomycin-D, or camptothecin (Samali and Cotter, 1996). Heat shock sufficient to induce HSP27 and HSP70 also protects nonneuronal cells from apoptosis (Samali and Cotter, 1996). When PC12 cells, a neural crest-derived cell line which in the differentiated state resembles sympathetic neurons, are transfected with a construct encoding antisense to HSP27, cytoplasmic, blebbing, cell shrinkage, and nuclear fragmentation occur in many transfected cells, suggesting that HSP27 may also play an antiapoptotic role in a neuronal cell line (our unpublished observations).

Approximately $50 \%$ of neonatal motor and sensory neurons die 1 week after peripheral nerve injury (Houenou et al., 1994). This may represent an absolute requirement of some of these neurons for target-derived growth factors, the failure of the upregulation of growth factors in the injured neurons providing autocrine or paracrine support, or an inability of the immature neurons to deal with the stress response associated with the injury, such as the generation of free radicals (Yip et al., 1984; Himes and Tessler, 1989; Sendtner et al., 1990). In the adult, however, the majority of sensory and motor neurons survive peripheral nerve injury. Although several studies in the past estimated an early small loss of sensory neurons after peripheral nerve injury, a recent reexamination of this issue failed to find evidence of cell loss until beyond 16 weeks after axotomy (Coggeshall et al., 1997). One well characterized apoptosis suppressor, Bcl-2, is not upregulated after sciatic nerve axotomy in the adult (Gillardorn et al., 1994). It is possible that increased HSP27 expression after peripheral axotomy in the adult contributes to the prevention of cell death. Cell death may not be prevented in the neonate, because the levels at birth are low or are not upregulated to the same extent.

\section{Conclusion}

We have found that HSP27, after an appearance late in development, is constitutively expressed at low levels in the adult dorsal root ganglion in medium- and large-sized primary sensory neurons. After damage to the peripheral, but not the central, axon of adult primary sensory neurons, HSP27 mRNA and protein are upregulated in most, if not all, of the axotomized neurons, and HSP27 protein is distributed to the central terminals of the injured neurons in the spinal cord. Given its actions in a variety of non-neuronal cells, this pattern of expression is compatible with roles for HSP27 both as a promoter of the survival of injured neurons and as a contributor to axonal regeneration. 


\section{REFERENCES}

Aigner L, Caroni P (1995) Absence of persistent spreading, branching, and adhesion in GAP-43-depleted growth cones. J Cell Biol 128:647-660.

Aldskogius H, Arvidsson J, Grant G (1985) The reactions of primary sensory neurons to peripheral nerve injury. Brain Res 373:15-21.

Barr FG, Emanuel BS (1990) Application of a subtraction hybridization technique involving phoactivatable biotin and organic extraction to solution hybridization analysis of genomic DNA. Anal Biochem 186:369-373.

Benndorf R, Hayes K, Ryazantsev S, Wieske M, Behlke J, Lutsch G (1994) Phosphorylation and supramolecular organization of murine small heat shock protein hsp25 abolish its actin polymerizationinhibiting activity. J Biol Chem 269:20780-20784.

Brady G, Barbara M, Iscove NN (1990) Representative in vitro cDNA amplification from individual hemopoietic cells and colonies. Methods Mol Cell Biol 2:17-25.

Brady G, Bilia F, Knox J, Hoang T, Kirsch IR, Voura EB, Miyamoto N, Boehmelt G, Iscove NN (1995) Analysis of gene expression in a complex differentiation hierarchy by global amplification of cDNA from single cells. Curr Biol 5:909-922.

Castro-Lopes JM, Coimbra A, Grant G, Arvidsson J (1990) Ultrastructural changes of the central scalloped (C1) primary afferent endings of synaptic glomeruli in the substantia gelatinosa Rolandi of the rat after peripheral neurotomy. J Neurocytol 19:329-337.

Castro-Lopes JM, Tavares I, Coimbra A (1993) GABA decreases in the spinal cord dorsal horn after peripheral neurectomy. Brain Res 620:287-294.

Chomczynski P, Sacchi N (1987) Single-step method of RNA isolation by acid guanidinium thiocyanate-phenol-choloroform extraction. Anal Biochem 162:156-159.

Chong M-S, Fitzgerald M, Winter J, Hu-Tsai M, Emson PC, Weise U, Woolf CJ (1992) GAP-43 mRNA in rat spinal cord and dorsal root ganglia neurons: developmental changes and re-expression following peripheral nerve injury. Eur J Neurosci 4:883-895.

Chong M-S, Reynolds ML, Irwin N, Coggeshall RE, Emson PC, Benowitz LI, Woolf CJ (1994) GAP-43 expression in primary sensory neurons following central axotomy. J Neurosci 14:4375-4384.

Chong M-S, Woolf CJ, Turmaine M, Emson PC, Anderson PN (1996) Intrinsic vs extrinsic factors in determining the regeneration of the central processes of rat dorsal root ganglion neurons: the influence of a peripheral nerve graft. J Comp Neurol 370:97-104.

Coggeshall RE, Lekan H, Doubell TP, Allchorne A, Woolf CJ (1997) Central changes in primary afferent fibers following peripheral nerve lesions. Neuroscience 77:1115-1122.

de Jong WW, Leunissen JA, Leenen PJ, Zweers A, Verseeg M (1988) Dogfish $\alpha$-crystallin. J Biol Chem 263:5141-5149.

Devor M, Govrin-Lippman R, Angelides K (1993) $\mathrm{Na}^{+}$channel immunolocalization in peripheral mammalian axons and changes following nerve injury and neuroma formation. J Neurosci 13:1976-1992.

DiStefano PS, Friedman B, Radziejewesk C, Alexander C, Boland P, Schieck CM, Lindsay RM, Wiegand SJ (1992) The neurotrophins BDNF, NT-3 and NGF display distinct patterns of retrograde axonal transport in peripheral and central neurons. Neuron 8:983-993.

Fitzgerald M, Wall PD, Goedert M, Emson PC (1985) Nerve growth factor counteracts the neurophysiological and neurochemical effects of chronic sciatic nerve section. Brain Res 332:131-141.

Gillardorn F, Wickert H, Zimmerman M (1994) Differential expression of bcl-2 and bax mRNA in axotomized dorsal root ganglia of young and adult rats. Eur J Neurosci 6:1641-1644.

Gold BG, Mobley WC, Matheson SF (1991) Regulation of axonal caliber, neurofilament content, and nuclear localization in mature sensory neurons by nerve growth factor. J Neurosci 11:943-955.

Higashi T, Takechi H, Uemura Y, Kikuchi H, Nagata K (1997) Differential induction of the mRNA species encoding several classes of stress proteins following focal cerebral ischemia. Brain Res 650:239-248.

Himes BT, Tessler A (1989) Death of some DRG neurons and plasticity of others following sciatic nerve section in adult and neonatal rats. J Comp Neurol 284:215-230.

Hokfelt T, Zhang X, Wiesenfeld-Hallin Z (1994) Messenger plasticity in primary sensory neurons following axotomy and its functional implications. Trends Neurosci 17:22-30.

Houenou LJ, Li L, Lo AC, Yan Q, Oppenheim RW (1994) Naturally occurring and axotomy-induced motoneuron death and its prevention by neurotrophic agents: a comparison between chick and mouse. Prog Brain Res 102:217-226.

Hu-Tsai M, Woolf CJ, Emson PC, Winter J (1994) Neurite outgrowth and GAP-43 mRNA expression in cultured adult rat dorsal root ganglion neurons: effects of NGF and prior axotomy. J Neurosci Res 39:634-645.

Huot J, Roy G, Lambert H, Chretien P, Landry J (1991) Increased survival after treatments with anticancer agents of chinese hamster cells expressing the human Mr 27,000 heat shock protein. Cancer Res 51:5245-5252.

Jakob U, Gaeslel M, Engel K, Buchner J (1993) Small heat shock proteins are molecular chaperones. J Biol Chem 268:1517-1520.

Kato H, Liu Y, Kogure K, Kato K (1994) Induction of $27 \mathrm{kDa}$ heat shock protein following cerebral ischemia in a rat model of ischemic tolerance. Brain Res 634:235-244.

Lavoie JN, Gingras-Breton G, Tanguay RM, Landry J (1993a) Induction of chinese hamster HSP27 gene expression in mouse cells confers resistance to heat shock. HSP27 stabilization of the microfilament organization. J Biol Chem 268:3420-3429.

Lavoie JN, Hickey E, Weber LA, Landry J (1993b) Modulation of actin microfilament dynamics and fluid phase pinocytosis by phosphorylation of heat shock protein 27. J Biol Chem 268:24210-24214.

Lavoie JN, Lambert H, Hickey E, Weber LA, Landry J (1995) Modulation of cellular thermoresistance and actin filament stability accompanies phosphorylation-induced changes in the oligomeric structure of heat shock protein 27. Mol Cell Biol 15:505-516.

Leslie TA, Emson PC, Dowd PM, Woolf CJ (1995) Nerve growth factor contributes to the upregulation of GAP-43 and preprotachykinin A mRNA in primary sensory neurons following peripheral inflammation. Neuroscience 67:753-761.

Mairesse N, Horman S, Mosselmans R, Galand P (1996) Antisense inhibition of the $27 \mathrm{kDa}$ heat shock protein production affects growth rate and cytoskeletal organization in MCF-7 cells. Cell Biol Int 20:205-212.

Marcuccilli CJ, Miller RJ (1994) CNS stress response: too hot to handle? Trends Neurosci 17:135-137.

Mehlen P, Chareyron P, Briolay J, Klemenz R, Arrigo AP (1995) Constitutive expression of human HSP27, Drosophila HSP27, or human alpha B-crystallin confers resistance to TNF- and oxidative stressinduced cytotoxicity in stably transfected murine L929 fibroblasts. J Immunol 154:363-374.

Mehlen P, Kretz-Remy C, Preville X, Arrigo A-P (1996a) Human hsp27, Drosophila hsp27 and human $\alpha \beta$-crystallin expression-mediated increase in glutathaione is essential for the protective activity of these proteins against TNF $\alpha$-induced cell death. EMBO J 15:2695-2706.

Mehlen P, Schulze-Ostoff K, Arrigo A-P (1996b) Small stress proteins as novel regulators of apoptosis. J Biol Chem 271:16510-16514.

Mehlen P, Hickey E, Weber LA, Arrigo A-P (1997) Large unphosphorylated aggregates as the active form of hsp27 which controls intracellular reactive oxygen species and glutathione levels and generates a protection against TNF $\alpha$ in NIH-3T3-ras cells. Biochem Biophys Res Commun 241:187-192.

Miller FD, Tetzlaff W, Bisby MA, Fawcett JW, Milner RJ (1989) Rapid induction of the major embryonic $\alpha$ tubulin mRNA, T $\alpha 1$, during nerve regeneration in adult rats. J Neurosci 9:1452-1463.

Moskowitz PF, Oblinger MM (1995) Sensory neurons selectively upregulate synthesis and transport of the beta III-tubulin protein during axonal regeneration. J Neurosci 15:1545-1555.

Plumier JC, Armstrong JN, Landry J, Babity JM, Robertson HA, Currie RW (1996) Expression of the 27,000 mol. wt heat shock protein following kainic acid-induced status epilepticus in the rat. Neuroscience 75:849-856.

Plumier JC, Hopkins DA, Robertson HA, Currie RW (1997) Constitutive expression of the $27 \mathrm{kDa}$ heat shock protein (Hsp27) in sensory and motor neurons of the rat nervous system. J Comp Neurol 384:409-428.

Pover CM, Orr MH, Coggeshall RE (1993) A method for producing unbiased histograms of neuronal profiles sizes. J Neurosci Methods 49:123-131.

Saklatvala J, Kaur P, Guesdon F (1991) Phosphorylation of the small heat-shock protein is regulated by interleukin 1, tumour necrosis factor, growth factors, bradykinin and ATP. Biochem J 277:635-642.

Samali A, Cotter TG (1996) Heat shock proteins increase resistance to apoptosis. Exp Cell Res 223:163-170.

Sendtner M, Kreutzberg GW, Thoenen H (1990) Ciliary neurotrophic factor prevents the degeneration of motor neurons after axotomy. Nature 345:440-441. 
Skene JHP (1989) Axonal growth associated proteins. Annu Rev Neurosci 12:127-156.

Uoshima K, Handelman B, Cooper LF (1993) Isolation and characterization of a rat hsp27 gene. Biochem Biophys Res Commun 197:1388-1395.

Verge VMK, Tetzlaff W, Richardson PM, Bisby MA (1990) Correlation between GAP-43 and nerve growth factor receptors in rat sensory neurons. J Neurosci 10:926-934.

Verge VMK, Richardson PM, Wiesenfeld-Hallin Z, Hokfelt T (1995) Differential influence of nerve growth factor on neuropeptide expression in vivo: a novel role in peptide suppression in adult sensory neurons. J Neurosci 15:2081-2096.

Wall PD, Gutnick M (1974) Ongoing activity in peripheral nerves: the physiology and pharmacology of impulses originating from a neuroma. Exp Neurol 43:580-593.

Wong J, Oblinger MM (1991) NGF rescues substance P expression but not neurofilament or tubulin gene expression in axotomized sensory neurons. J Neurosci 11:543-552.

Woolf CJ, Reynolds ML, Molander C, O'Brien C, Lindsay RM, Benowitz LI (1990) GAP-43 a growth associated protein, appears in dorsal root ganglion cells and in the dorsal horn of the rat spinal cord following peripheral nerve injury. Neuroscience 34:465-478.

Woolf CJ, Shortland P, Reynolds ML, Ridings J, Doubell TP, Coggeshall RE (1995) Central regenerative sprouting: the reorganization of the central terminals of myelinated primary afferents in the rat dorsal horn following peripheral nerve section or crush. J Comp Neurol 360:121-134

Woolf CJ, Ma Q-P, Allchorne A, Poole S (1996) Peripheral cell types contributing to the hyperalgesic action of nerve growth factor in inflammation. J Neurosci 16:2716-2723.

Wu W, Welsh MJ (1996) Expression of the 25-kDA heat-shock protein (HSP27) correlates with resistance to the toxicity of cadmium chloride, mercuric chloride, cis-platimun(II)-diammine dichloride, or sodium arsenite in mouse embryonic stem cells transfected with sense or antisense HSP27 cDNA. Toxicol Appl Pharmacol 141:330-339.

Yip HK, Rich KM, Lampe PA, Johnson Jr EM (1984) The effects of nerve growth factor and its antiserum on the postnatal development and survival after injury of sensory neurons in rat dorsal root ganglia. J Neurosci 4:2986-2992. 